\title{
Partial Replacement of Berseem Hay by Atriplex halimus and Atriplex nummularia Nutrients Utilization in Barki Sheep
}

\author{
Mahmoud Yassin Mohamed*, Adel M. Saber, El- Saeed A. El-Wakeel, Mohamed M. \\ Anwar, HeshamGhobashy, Lamiaa F. Abdel-Mawla and Mohamed M. Eissa
}

\author{
Animal Production Research Institute (APRI), Agricultural Research center (ARC), \\ NC 12618, Dokki, Giza, Egypt \\ *Corresponding author
}

\section{Keywords}

Sheep growth, Atriplex, Berseem hay, Nutrients digestibility

Article Info

Accepted:

22 June 2020

Available Online:

10 July 2020
The deficiency of animal feed in semi-arid places leads to using of non-traditional resources, like saline plants, as animal feed. Therefore, this experiment was conducted to compare the consequences of replacing berseem hay $(\mathrm{BH})$ with various proportions of Atriplex halimus (AH) and Atriplex nummularia (AN). Two trials were conducted to determine salt surfing digestion, growth performance, and feed efficiency. Twenty-one adult Barky lambs were used in the first trial. Also, thirty-five growing Barki lambs were used in the second trial. In both trials animals were divided into seven groups and each group received one of seven dietary treatments. The present results reported that leaves and twigs of AN contained higher levels of CP, FAT, and NFE than in AH treatments. They had significant $(P<0.05)$ effects on dry matter intake (DMI), lambs' body weight, and digestibility. In contrast, Degradability, higher gas production and in vitro fermentation range of $\mathrm{BH}$ to that these substrates had a higher nutritional value than the other browse species. Lambs receiving $\mathrm{BH}$ consumed $(P<0.05)$ more feed compared to those received $\mathrm{AH}$ or AN. Lambs weight, which fed a diet contained $50 \%$ or $25 \%$ of $\mathrm{AH}$ or AN increased compared with those feed $100 \%$ Atriplex only. The containing diets up to $50 \%$ of AN had no adverse effects on DMI and digestibility. In comparison, supplementing over $25 \% \mathrm{AH}$ in diets decreased $(P<0.05)$ the digestibility of dry matter and organic matter. BH had the best relative feed value (203.92\%), while AH had the lowest $(123.37 \%)$. Economic efficiency criteria supported a conclusion that favored the $50 \%$ AN (T4) than other treatments. In conclusion, up to $50 \%$ of BH can be replaced with AN without adverse effects on feed intake and dry matter digestion.

\section{Introduction}

Feed shortage is a challenge in developing countries, thus imposing a big burden on human food costs, especially when increasing population. In Egypt, The hole among the requirement and availability for feeding cattle of feed resources four million tons TDN according to FAO (2008). In semi-arid areas, the availability of conventional feed resources is declining as the livestock population increases. 
In this area in Egypt, particularly during hot summer and early autumn seasons, over there a great shortage in animal feedstuffs, also, recently the price of energy sources had dramatically increased with the elevating requirements for animal feeding. So the inflation of feed prices encouraged animal nutritionists to search for cheap high-energy feed ingredients. Therefore the scarcity of animal feed in semi-arid places leads to the use of salt plants as animal feeds.

In Egypt, salty plants are common because there are many brackish areas. Several attempts have made to get used to alternative forages, especially in the summer season, when green forages are lack and animals are underfed. Atriplex halimus (AH) and Atriplex nummularia (AN) have great potential because they are known to withstand salinity and dehydration in addition to the high content of crude protein, fibers, and mineral contents. Drought resistance allows browsing during the annual dry season when no other feed sources are available (El-Shaer, 2005). Saltbush shrub could use in the rations of cattle, sheep, and goats (Aganga et al., 2003).Obeidat et al., (2016)reported that the potential of inserting the $\mathrm{AH}$ up to $150 \mathrm{~g} / \mathrm{kg}$ in the fattening rations of Awassi sheep without any harmful influences on growth rate and reducing feeding cost.

Also, Hintsa et al., (2018) reported that replacing concentrate feed with Atriplex nummularia insect up to $20 \%$ did not alter DMI, body weight gain, and carcass components. So, using this plant as an alternative feed resource for livestock may mitigate the shortage of feed sources for smallholder farmers. Therefore, it was the main goal of the present study to illustrate the effect of replacing $\mathrm{BH}$ by specific proportions of $\mathrm{AH}$ and $\mathrm{AN}$ on growth performance and feed utilization of Barki lambs.

\section{Materials and Methods}

This study conducted in the Animal Production Research Station Borg El-Arab. Which stretches along $525 \mathrm{~km}$ on the Mediterranean Sea, west of Alexandria city at latitudes $21^{\circ}$ and $31^{\circ}$ north $21^{\circ}$ and $31^{\circ}$ north and longitudes 25 degrees and 35 degrees East, the average air temperature ranges from $13{ }^{\circ} \mathrm{C}\left(56{ }^{\circ} \mathrm{F}\right)$ in December and January to $26^{\circ} \mathrm{C}\left(79^{\circ} \mathrm{F}\right)$ in July and August.

\section{Ethical approval}

All animal procedures performed following the standards set forth guidelines for the care and use of experimental animals by the Animal Ethics Committee of Animal Production Research Institute (APRI), Agricultural Research Centre (ARC), Ministry of Agriculture, Egypt. Especially, cannulated Barki sheep well treated under good veterinary care.

The cannulas have been installed by APRI ethical approval to the animals after sterilization and anesthesia well with the provision of all appropriate conditions and remained under intensive veterinary care during the experimental period in Animal Production Research Station Borg El-Arab.

\section{Animal welfare statement}

All animals were kept under the same management and hygienic conditions. Lambs were kept in a ventilated barn and housed separately in shaded pens with concrete flooring, in addition to natural lighting through windows along either side of the building. The pens cleaned in the morning and afternoon after feeding. Diets provided at $8 \mathrm{am}$ and $3.00 \mathrm{pm}$. and refusals were collected $24 \mathrm{~h}$ later. Freshwater and mineral licks provided to animals as free choices. 


\section{Experimental design}

In the first trial, twenty-one Barki adult lambs were used (weighed $35.26 \pm 0.66 \mathrm{~kg}$ ); they were randomly assigned into equal seven groups (3 each) as a digestion trial to determine digestibility and feeding value. Each group received one of seven dietary treatments according to NRC (1985) as follows: $60 \%$ concentrate feed mixture (CFM) and $40 \%$ chopped $\mathrm{BH}$ and served as control (T1), 60\% CFM and 40\% dried AN foliage (T2), 60\% CFM and $40 \%$ dried AH foliage (T3), $60 \%$ CFM and $25 \%$ BH plus $25 \%$ AN (T4), $60 \%$ CFM and $25 \%$ BH plus $25 \% \mathrm{AH}$ (T5), $60 \% \mathrm{CFM}$ and $30 \% \mathrm{BH}$ plus $10 \% 25 \%$ AN (T6) and 60\% CFM and 30\% BH plus $10 \%$ AH (T7). Animals kept in metabolic cages and weighted at the beginning and final of the digestibility trial that continued for 21 days (14 days as an adaptation period followed by seven days as a collection period). Feed amounts, residuals, fecal output, and urine volume and recorded daily. Daily feed intake of diets (the difference between the offered feeds and refusals) recorded for each animal for 18 weeks, and representative samples of diets recorded daily.

In the second trial, thirty-five Barki lambs were used (singles born, aged three months and weighed $12.16 \pm 0.11 \mathrm{~kg}$ ), randomly assigned into the same experimental groups (5 each). Animals were weighed biweekly for 20 weeks, the first two weeks were an adaptation period, and the other 18 weeks were feeding period. Feeds were offered in two balanced meals at 07:00 and 18:00 h, respectively.

\section{Preparing experimental forages}

$\mathrm{AH}$ and $\mathrm{AN}$ tree fodder (leaves and twigs) were harvested from the northwest coast, west of Alexandria. Samples from each type of herb were dried (up to $200 \mathrm{~g}$ ) at $55^{\circ} \mathrm{C}$ for 48 hours and passed to a $1 \mathrm{~mm}$ screen for subsequent chemical and laboratory analysis. Likewise, the pooled samples collected from AH\&AN plus BH (i.e., control fodder) for analysis of all feed components, fecal, and urine samples, according to AOAC (2000).

\section{Macro and micro-mineral}

Mineral content was determined by sample dry ashing at $550^{\circ} \mathrm{C}$ in a muffle furnace; the ash was dissolved in $10 \% \mathrm{HCl}$ and filtered (Oshodi, 1992). Sodium (Na) and potassium (K) were measured using a flame model (Jenway PFP7) photometer; $\mathrm{Ca}, \mathrm{Mg}, \mathrm{Zn}, \mathrm{Fe}$, $\mathrm{Pb}$, and $\mathrm{Cu}$ were determined using atomic absorption spectrophotometer model (Unicam929) in all dietary while condensed tannins were determined according to the procedures of Porter et al., (1985).

\section{Gas production}

Gas production was evaluated in vitro by Menke (1988) methods. Rumen fluid collected from three rumina cannulated Barki sheep. Incubation carried out at $39{ }^{\circ} \mathrm{C}$ and gas production was read at $3,6,12,24$, and $48 \mathrm{~h}$. The remaining volume of gas recorded, according to Theodorou et al., (1994). The cumulative gas volume represented as a milliliter of gas produced per $200 \mathrm{mg} \mathrm{DM}$ and corrected for blanks. The gas volume of the control ration (i.e.,BH) used as standard.

\section{Blood sampling and biochemical assay}

Blood samples $(10 \mathrm{ml})$ collected at 08:00 am from $12 \mathrm{~h}$ fasted animals in non-heparinized tubes via the jugular venipuncture from three lambs within each group before feeding and at the end of the growing period to avoid any diurnal effect on the minerals levels. Blood samples centrifuged (4000 rpm for $20 \mathrm{~min}$. 5 ${ }^{\circ} \mathrm{C}$ ). All serum samples analyzed for total protein and albumin, according to Rodkey (1965). Globulin calculated by subtracting, 
whereas albumin/globulin ratio was estimated. Plasma urea-N, creatinine, ALT, and AST were measured, according to Berthelot (1959), Seelig and Wust (1969), and Wilkinson et al., (1972), respectively.

\section{Economic efficiency}

Economic efficiency was calculated as total output/total input according to the local prices (where one-ton concentrate $=4500 \mathrm{LE} ; \mathrm{AH}=$ 500 LE; AN $=500$ LE; Hay $=3000$ LE; Kg live body weight of lambs $=65$ LE. Relative feed value (RFV) developed by the Hay Marketing Task Force of American Forage and Grassland Council (Table 1) is the most widely used index for forage quality in the marketing of hays (Rohweder et al., 1978). RFV of legume shrubs was calculated from the estimates of dry matter digestibility (DMD) and dry matter intake (DMI). Metabolizable energy (ME, MJ/Kg DM) and organic matter digestibility (OMD) were estimated at $24 \mathrm{~h}$ post gas collection, according to Menke (1988). Following are the used equations:

DMD $(\%)=88.9-(0.779 \times$ ADF \% $)$

DMI $(B W \%)=120 \div$ NDF \%

RFV $=($ DMD $\times$ DMI $) \div 1.29$

$\mathrm{ME}=2.20+0.136 \mathrm{GV}+0.057 \mathrm{CP}$ $\mathrm{OMD}=14.88+0.889 \mathrm{GV}+0.45 \mathrm{CP}+0.651 \mathrm{~A}$

Where, $\mathrm{ADF}=$ Acid detergent fiber $(\mathrm{DM} \%)$; $\mathrm{NDF}=$ Neutral detergent fiber $(\mathrm{DM} \%)$; BW = body weight; $\mathrm{GV}=$ Total gas volume $(\mathrm{ml} / 0.2 \mathrm{~g} \mathrm{DM}) ; \mathrm{CP}=$ crude protein; $\mathrm{CF}=$ crude fibre.

\section{Statistical analysis}

Data were statistically analyzed using SAS procedure (2003) for Windows software. ANOVA was used to test the effect of treatments, and the differences between means detected by Duncan's Multiple Range Test (Duncan, 1955).

\section{Results and Discussion}

\section{Chemical composition}

Data presented in Tables2, and 3 showed the nutrients proximate analyses of Berseem hay $(\mathrm{BH})$, the two Atriplex species, and their mixture forage treatments. Data presented in these tables showed that nutrients of the two Atriplex species were comparable to those of berseem hay; it observed that CF, FAT, NEF, $\mathrm{OM}$, and ADL content were noticeably higher with $\mathrm{BH}$ than the two Atriplex species. While these browse of Atriplex had significant $(P<$ 0.05 ) higher $\mathrm{CP}, \mathrm{DM}, \mathrm{NDF}, \mathrm{ADF}$, and ash than in BH. On the other hand, chemical compositions percentage for mixtures between $\mathrm{BH}$ and two species of Atriplex as a mediator between them. The values of dry matter contents of $\mathrm{BH}$ and the two Atriplex species were relatively close, but the two Atriplex species contained lower levels of organic matter. The foliage of AH provided a higher level of ash and $\mathrm{Na}$ $(25.43 \% \& 37008.01 \mathrm{ppm})$ than that of AN (23.80\%\& 9037.88ppm). A similar trend recorded by Fayed et al., (2010) and Helal et al., (2018).

The two browse of Atriplex understudy had $\mathrm{CP}$ values above $10 \%$, which are higher than sthe minimum required in the diet for adequate digestive activities. Results showed that $\mathrm{CP}$ content for AH\&AN treatments identical to that obtained by Mueller-Harvey (2006) and Gemeda and Hassen (2015). Who determined that feeds, which contain less of $8 \% \mathrm{CP}$ could not provide the ammonia levels required by rumen microbes for optimum activity. Atriplex halimus and Atriplex nummularia fall within the range of benefits (12-14\%) reported by Chriyaa and Boulanouar (2000) and Aganga et al., (2003).Where CP content of browsing fodders is an indication of its nutritional quality, this justifies their use as supplements to poor quality natural pastures 
and crop residues (Rubanza et al., 2003).Salem et al., (2005) indicated that browsing is potential as nitrogen supplementation for ruminants fed lowquality fodders through the dry season in semi-arid regions. Moreover, shrubs and multipurpose trees have become a useful feed for ruminants alternative feed in the harsh semi-arid region (Eissa et al., 2015). The slight variation in the chemical composition of salt bushes among the different studies could be attributed to differences in soil characteristics and the stages of plant growth when sampling.

The phytochemical screening of the treatments revealed that they contained condensed tannins, while the $\mathrm{BH}$ was utterly devoid of them (Table 2). Condensed tannin (CT) levels ranged from 0.47 to $9.33 \%$ of DM, T2 showed the highest standards of CT followed by T4, T6, T3, T5, and T7, according to the ratio of both types of Atriplex in forge. CTs bind to the protein and/or carbohydrates to form under gradable complexes, which may reduce ruminal fermentation metabolism and nutrient digestibility. Therefore, the quantification of tannins was indispensable before using such forages for feeding. AH was less palatable than $\mathrm{BH}$. This result might be due to high ash and $\mathrm{Na}$ contents. Moreover, $\mathrm{AH}$ contained considerable amounts of total tannin (9.33\%), which appeared to be an anti-nutritional factor, reduced its palatability. Getachew et al., (2002) found that total tannin content in browsed plant species was ranged from 7 to $214 \mathrm{~g} / \mathrm{kg} \mathrm{DM}$ Atriplex halimus is characterized by high levels of oxalate, tannic phenols, condensed, and hydrolyzable tannins than Atriplex nummularia, which explains its low palatability (Abu-Zanat, 2005).

Significant differences were observed in the macro-mineral contents of $\mathrm{AH}, \mathrm{AN}$, and $\mathrm{BH}$ (Table 3). Among them, $\mathrm{Ca}$ and $\mathrm{Na}$ were highest (44020.02and $37008.01 \mathrm{ppm}$ ) in $\mathrm{AH}$ than $\mathrm{AN}$, and $\mathrm{BH}$. $\mathrm{Ca}$ requirement for maintenance of dairy animals was 0.27$0.57 \%$, and for lactating animals, it was 0.43 $0.77 \%$ (NRC, 2001). The concentration of $\mathrm{Ca}$ was higher than the recommended levels. However, it was reported that excess $\mathrm{Ca}$ can disturb the absorption of trace elements (NRC, 2001). The concentration of $\mathrm{Ca}$ and $\mathrm{Na}$ were higher than the recommended levels. However, it was reported that excess $\mathrm{Ca}$ can disturb the absorption of trace elements (NRC, 2001). While the recommended level of $\mathrm{Na}$ in forages is $0.08-0.1 \%$ (NRC, 2001).Mg, one of the critical constituent of chlorophyll in green plants, is normally present in abundance in feeds. Its content did not vary much and the mean values ranged from 515.65to $2322.20 \mathrm{ppm}$. Ruminant animals are generally at risk from hypomagnesemia when $\mathrm{Mg}$ in feed and forages is less than the recommended level i.e. $0.12 \%-0.2 \%$ on DM basis (NRC, 1985). So from a nutritional point of view, both $\mathrm{Ca}$ and $\mathrm{Mg}$ contents were adequate in top feeds to meet the requirement.

Like macro-minerals, significant differences were also observed in the contents of different micronutrients in the tree species (Table 3). Among the micronutrients, Fe concentration was significant $(P<0.05)$ higher in $\mathrm{AH}(544.76 \mathrm{ppm})$ than in $\mathrm{BH} \quad(471.20$ ppm), and its normal requirement is $30-60$ ppm on DM basis for ruminant animals (McDowell, 1992). Fe is a vital constituent of blood haemoglobin and cofactor of many enzymes. While deficiency can cause anemia, overabundance might result in nutritional imbalances. Higher $\mathrm{Fe}$ might interfere with $\mathrm{Cu}$ and phosphate absorption and metabolism. The maximum tolerable of $\mathrm{Fe}$ in forages is $1000 \mathrm{ppm}$, and it is least toxic of all the essential trace elements for livestock (McDowell, 1992). Mn deficiency was reported to cause impaired growth, skeletal, 
and infant abnormalities in animals (Hussain and Durrani, 2008), but the excessive amount decreases appetite. The level of $\mathrm{Mn}$ in both berseem hay and Atriplex halimus was quite higher than its required level of $20 \mathrm{ppm}$. Higher levels of $\mathrm{Fe}$ and $\mathrm{Mn}$ in feeds are in agreement with other reports (Hussain and Durrani, 2008).

\section{Relative feed value (RFV)}

Table 4 showed that Berseem hay had the best DMD, DMI, and RFV (73.48\%, 3.58\% $\& 203.92 \%$, respectively), while Atriplex halimus had the lowest $(57.83 \%, 2.15 \%$ $\& 123.37 \%$, respectively). The grade of browse fodders, Berseem hay and their mixture ranged from 2 to prime in the following order: $\mathrm{T} 2=2 ; \mathrm{T} 3=1 ; \mathrm{T} 4=1 ; \mathrm{T} 5=1$; T6 $=$ Prime; $\mathrm{T} 7=$ Prime, according to the standard assigned by Hay Market Task Force of American Forage and Grassland Council.

Okunade et al., (2014) reported that estimated DMD and DMI of the browse fodders ranged from $61.50 \%$ and $2.23 \%$ in D. microcarpum to $73.53 \%$ and $3.55 \%$ in A. Africana, respectively. A. Africana had the best RFV value (202.94\%), while E. Africana had the lowest RFV (114.43\%). The grade of the legume browses ranged from 4 to prime in the following order: D. microcarpum $=4 ; E$. Africana $=3 ; P$. thonningii $=2 ;$ D. oliveri $=2$; $P$. erinaceus $=1$; A. Africana $=$ prime in Nigeria. All the selected six legume browses except $D$. microcarpum may be regarded as having high relative nutritive value for ruminants. At the same time, Zhou et al., (2011) reported that DMD of shrubs ranged from $51.03 \%$ in D. Triangular to $72.75 \%$ in C. didymobotrya. DMI ranged from 2.17 in $D$. triangula to $5.68 \%$ in $C$. didymobotrya. RFV ranged from $85.9 \%$ in D. triangula to $321 \%$ in $C$. didymobotrya. The grades of Cratylia argentea, Leucaena leucocephala, Flemingia macrophylla, Cajanus cajan, Dendrolobium triangular, Cassia didymobotrya, Cassia bicapsularis and Acacia farnesiana were 2, prime, 2, 1, 4, prime, prime and prime, respectively, for several tropical legumes in China. Besides, the overall RFV is lower than mean value (181.00) for the quality standard followed the same trend as reported by the same authors.

The predicted metabolizable energy and organic matter digestibility from gas production for $\mathrm{BH}$, browse of $\mathrm{AH}, \mathrm{NH}$, and their mixture forage treatments are presented in Table 5.

The predicted ME in seven forages varied widely, being particularly high in Berseem hay and their mixture forage treatments (Table 4). While browse of Atriplex halimus and Atriplex nummularia had significantly lower values of ME. The data showed that there was no significant difference among $\mathrm{T} 1$, $\mathrm{T} 6$ and T7. There was a positive correlation between metabolisable energy calculated from in vitro gas production together with $\mathrm{CP}$ and fat content with a metabolisable energy value of conventional feeds measured in vivo (Menke, 1988). Results showed that metabolisable energy values reduced $(P<$ $0.05)$ in $\mathrm{T} 2$ compared with other treatments. This result may be attributed to the lower energy content of $\mathrm{AH}$ and $\mathrm{AN}$ than $\mathrm{BH}$ These results are in agreement Shaker et al., (2014). Salem et al., (2005) found that animal performance improved by feeding Atriplex supplemented with sated with barley than those fed Atriplex alone.

The organic matter digestibility (OMD)\% was higher $(P<0.05)$ in $\mathrm{BH}$ than $\mathrm{AH}$ and AN(Table 4). The OMD differed significantly $(P<0.05)$ among treatments. However, the subtropical feeds contained considerable amounts of secondary plant metabolites, particularly tannins, which are associated with a reduction in OMD (Waghorn and Shelton, 
1997).In vitro gas measurement and chemical composition are used in multiple regression equations (Van Soest, 1994; Waghorn et al., 1997), who found a high precision in prediction of in vivo OMD. This group further used a correlative approach to predict the ME content of feed by in vitro gas volume measurements and chemical constituents. It concluded that the prediction of ME is more accurate when based on gas and chemical constituents measurements as compared to calculations based on chemical components only.

\section{Gas production}

The cumulative gas volume at $3,9,12,24$, and $48 \mathrm{~h}$ after incubation of $\mathrm{BH}, \mathrm{AH}, \mathrm{AN}$, and their mixture are presented in are shown in Table 5 and Figure 1. They were significant $(P<0.05)$ different among treatments. It can be seen that gas production reached the highest point at $48 \mathrm{~h}$ of fermentation. Cumulative gas volume at each sampling time was affected $(P<0.05)$ by a variety of feedstuffs. This finding indicated that the degradability of Atriplex halimus and Atriplex nummularia browses are different. The low gas production from Atriplex halimus could be related to the low feeding value of these feeds. Gas production is directly proportional to the substrate degradation rate (Dhanoa et al., 2000). Menke et al., (1988) suggested that the gas volume after $24 \mathrm{~h}$ of incubation has a relationship with metabolizable energy in feedstuffs. Sommart et al., (2000) reported that gas volume is a good parameter to predict digestibility, fermentation end-product, and microbial protein synthesis of the substrate by rumen microbes in the in vitro system. Additionally, in vitro, dry matter and organic matter digestibility were shown to have a high correlation with gas volume (Sommart et al., 2000). Gas volumes also have a close relationship with feed intake and growth rate in cattle (Blummel and Ørskov, 1993). The initial gas production presented in was highly significant $(P<0.05)$ in berseem hay in comparison with other roughages. The fast initial gas production was significant $(P<$ 0.05) in $\mathrm{BH}$ in comparison with other treatments, the highest cumulative gas production was observed in $\mathrm{T} 1$, which was followed by T7, and the lowest was obtained in T2. Variation in cumulative gas production is due to the high content of the berseem hay from NFE, which has a positive correlation with gas production. On the other hand, cell wall content (NDF \& ADF) was negatively correlated with gas production at all incubation times and estimated parameters. This may tend to reduce the microbial activity by increasing the adverse environmental conditions as incubation time progress. Also, the relatively high level of ADL as shown in Table 2 explains in part the limited in vitro degradation and therefore the lower amount of gas produced. The final net gas volume at $48 \mathrm{~h}$ after incubation was significantly $(P<$ $0.05)$ increased among treatments. Isah et al., (2012) confirmed that the forages degradability within $48 \mathrm{~h}$ could consider as equivalent to digestion.

Gas production can be regarded as an indicator of carbohydrate degradation and the low gas production in Atriplex halimus is explained by condensed tannin's binding to the carbohydrate and then by the inhibition of enzymes or microorganisms complexing with lignocellulose, and preventing the microbial digestion (Getachew et al., 1998).

Subtropical feeds contain considerable amounts of phenolic compounds that reduced in vitro gas production correlation between the change in gas production in the presence of tannin binding agent and phenolic contents of browses were consistent with those of Khazaal et al., (1996).

Table 5 showed the rising of the cumulative 
gas volume by the browse fodders mixture with increasing berseem hay percentage in vitro incubation hour. It is well known that gas production is the result of carbohydrates fermentation to acetate, propionate, and butyrate (Getachew et al., 1998), whereas, protein fermentation does not lead to much gas production (Khazaal et al., 1995). In the current study, browse of Atriplex halimus and Atriplex nummularia generally had moderate gas production potentials; gas production of the forages in vitro indicated that further degradation of DM was still possible beyond $48 \mathrm{~h}$. Many factors such as the level of fibers, the presence of secondary metabolites, and potency of the rumen liquor have reported by Bamikole et al., (2004) to determine the amount of gas to be produced during fermentation. Degradability, higher gas production and in vitro fermentation range of berseem hay had a higher nutritional value than the other browse species. In contrast, low-gas production of Atriplex halimus could be attributed to its high amount of tannins, in agreement with Isah et al., (2012).

Notably, the absolute value ( $|\mathrm{a}|)$ can utilize to represent the ideal fermentation of a soluble fraction. The total gas production was highest in $\mathrm{BH}$. The soluble fraction makes it easily attachable by ruminal microorganisms and leads to higher gas production. Gas volumes in asymptote (b) describe the fermentation of the insoluble fraction. The $\mathrm{b}$ values ranged from the most elevated $\mathrm{T} 1$ to the lowest $\mathrm{T} 2$, and the gas volume rate (c) ranked from the fastest T1 to the slowest (T2). The cumulative gas volume created by experimental fodders raised by increasing incubation time in vitro, high levels of gas production mentioned in $\mathrm{T} 1$, possibly affected by fractions of soluble carbohydrates readily available for ruminal microbes. The potential gas production range $(\mathrm{a}+\mathrm{b})$ classified from the highest $\mathrm{T} 1$ to lowest T2. Generally, the potential for gas production in current processors was high, due to the high carbohydrate content (especially NDF).

The saltbush hay can be used as a source of protein (13\%) and minerals. The Atriplex species are characterized by high salt content as well as high levels of $\mathrm{Na}, \mathrm{Ca}, \mathrm{P}, \mathrm{Mg}$, and $\mathrm{K}$ components (Aganga et al., 2003). However, it is a poor source of energy, like wheat straw, and should be supplemented with high energy feeds. Salem and Smith (2008) observed a low energy content in AN, which could be a limiting issue to satisfy the animal requirements. The lower feed intake in animals fed the Atriplex hay is attributed to its high mineral content. Norman et al., (2008) noticed that the high ash content in AN hay restricted the feed intake.

In this study, the average daily feed intake, growth performance, and feed efficiency are summarized in Table 6. Total and daily DM intake tended to increase significantly $(P<$ 0.05) with $\mathrm{T} 1$ expressed as $1200 \mathrm{~g} \& 95$ $\mathrm{g} / \mathrm{kg}^{\mathrm{w} 0.75}$, respectively, for lambs compared to other groups, while the lowest values recorded with T2 (750g \& $\left.60 \mathrm{~g} / \mathrm{kg}^{\mathrm{w} 0.75}\right)$. Treatments had a significant $(P<0.05)$ effect on voluntary feed intake. Lambs receiving berseem hay consumed higher amounts of feed compared to those fed the $\mathrm{AH}$ or $\mathrm{AN}$, and there were significant differences in feed intake between lambs fed AH or AN. Relative intakes of saltbushes to berseem hay averaged $62 \%$ and $75 \%$ for $\mathrm{AH}$ and $\mathrm{AN}$, respectively. The lower DMI of saltbushes as compared to those of berseem hay could be associated with higher salt content and lower organic matter digestibility of the consumed saltbushes. In the present study, embedding Atriplex nummularia browse up to $50 \%$ in diets maintained OMD slightly above $50 \%$.

On the other hand, there was a significant $(P<$ $0.05)$ decrease in lamb's weight fed on $\mathrm{AH}$ alone, which can be attributed to small 
differences that accumulate over time due to energy restriction, and diminished DM intake. Moreover, the high consumption of ash and $\mathrm{Na}$ can cause mineral imbalances when intake is over a long period. Also, AH contained considerable amounts of total tannin $(9.33 \%$ of DM), which seems to be an anti-nutritional factor and decreased its palatability (Norman et al., 2008). However, the weight of lambs fed $50 \%$ Atriplex hay of the roughage amount was not affected despitethe reduced feed intake of these animals. High OMD in AN treatment compared to $\mathrm{AH}$ treatment may be due to $\mathrm{AH}$ content of elevated levels of secondary chemical compounds and ash, this agreement with Menke (1988) andGemeda and Hassen, (2015).Dry matter intakes of saltbushes in the present study (60 to $65 \mathrm{~g}$ $\mathrm{DM} / \mathrm{kg}^{\mathrm{w} 0.75}$ ) were lower than those reported by other researchers (Abu-Zanat, 2005). The daily intake of Barbarian ewes were 117 and $90 \mathrm{~g} \mathrm{DM} / \mathrm{kg}^{\mathrm{w} 0.75}$ for fresh shrubs of $\mathrm{AH}$ and AN, respectively (Le Houerou, 1991). In Spain, daily intake by Segurena ewes under pen feeding conditions averaged $1.5 \mathrm{~kg}$ or 88 $\mathrm{g} \mathrm{DM} / \mathrm{kg}^{\mathrm{w} 0.75}$ for $\mathrm{AN}$ and $1.4 \mathrm{~kg}$ or $73 \mathrm{~g}$ $\mathrm{DM} / \mathrm{kg}^{\mathrm{w} 0.75}$ for AH (Abu-Zanat, 2005). However, Wilson (1977) reported that daily DMI of AN by sheep averaged $550 \mathrm{~g}$, which is lower than values obtained in the current study. The variations in DMI of forage treatments could be attributed to many factors, including the ratio of leaves to twigs size, digestibility, salt content, and previous exposure of animals to saltbush (Allison, 1985).

Many studies suggested that the diameters of twigs should be less than $5 \mathrm{~mm}$ to be grazable by animals (Roundy et al., 1989). Twigs having diameters more than $10 \mathrm{~mm}$ are mostly indigestible. A large proportion of these indigestible substances in the diet could be accumulated in the animals' gut and consequently limited their feed intake (Rehman et al., 1994). Previous experience and adaptation of animals to saltbushes considerably affect the consumption of browse (Abu-Zanat, 2005). Le Houerou (1991) reported that sheep become adapted to saltbush and increased their consumption of forage over 3-5 weeks. During the first two weeks of the experiment conducted by AbuZanat (2005), Segurena dry ewes lost weight on saltbush diet (Atriplex nummularia) and then live weight improved in the third week. This suggests that during the first two weeks of the experiment, ewes underwent an adaptation process; the animal condition is an essential factor that determines the nutrient requirements, thus DMI of the animal. The significant differences in chemical composition and intake among the different Atriplex species in addition to differences in breeds, body weights and body condition of animals are major factors contributing to variability in dry matter intakes of saltbushes in the different studies.

Growth performance of Barki lambs fed experimental rations were presented in (Table $6)$. The obtained results revealed significant $(P<0.05)$ differences among groups fed different rations in final body weight, total body gain, and daily body gain. Final body weight for sheep, which fed a diet contained $50 \%$ or $25 \%$ of AHorAN increased compared to those fed control diet. This improvement could be attributed to the increase in DMI in these groups. This disagreement with the finding of Brown et al., (2018), who reported that final body weight where similar in sheep fed a diet contained $50 \%$ of dietary shrubs compared with other treatment groups. On the other hand, Aganga et al., (2003) found reduced feed intake and digestibility rate of animals fed halophyte shrub, which led to weight loss. The current results showed a wide range of dietary concentrations of the condensed tannin percentage ranged from 0.47 to 9.33 in seven forage treatments (Table 2 ), which reflected on the improved daily 
weight gain of Barki lambs on fresh temperate forages. Concerning ruminant nutrition, specific levels of tannins consider beneficial effects including better utilization of dietary protein, faster body weight or wool growth, higher milk yield, increased fertility, and improved animal welfare and health through the prevention of bloat and reduced worm burdens (Mueller-Harvey, 2006). The present results are in agreement with those reported by many studies (Barry et al., 2001; Salem and Smith, 2008; Gemeda and Hassen 2015; Eissa et al., 2015).

Data in Table 6 indicated that the economic efficiency (E.E.) was better with T5 compared to other groups, in terms of growth performance of lambs with treatments. In this respect, Eissa et al., (2015) found that E.E. improved significantly by replacing legumes trees with ammoniated wheat straw in sheep rations. Saltbushes mixture recorded a reduction in feed cost of $\mathrm{Kg}^{\mathrm{w} 0.75}$, about $53 \%$ for sheep compared to the control group due to the lower price of saltbushes mixture compared to berseem hay. The results are in agreement with those reported by Fayed $e t$ al., (2010) and Sadek et al., (2020).
Data of blood parameters shown in Table 7 revealed that the lowest concentrations of total proteins (T.P.), albumin (A.L.) and globulin (G.L.) were detected with T2. These findings are in agreement with those reported by Eissa et al., (2015). This reduction of T.P. in animals fed salt shrubs might be owing to the high content of tannins in these plants. In agreement, Reed et al., (1995) and MuellerHarvey (2006), since they reported that the high content of tannins in Acacia probably decreases the digestibility of crude protein. Coles (1986) found that reduced absorption of dietary constituents from the intestinal tract leads to hypoproteinemia. Mahmoud (2001) reported that a lower globulin concentration in sheep might be due to the presence of a high level of tannins that form complexes with diet. Thus, higher concentrations of T.P., AL, and G.L. in T1 than T2 and T3 might be owing to $\mathrm{N}$ concentration. The same trend found in the blood urea-N level. Generally, this can be attributed to the high protein content in T1, which is utilized efficiently by rumen microflora (Shaker et al., 2014). Also, creatinine levels were significant $(P<0.05)$ increased in treatments.

Table.1 Quality standards of shrubs, grass, and mixture of them

\begin{tabular}{|c|c|c|c|c|}
\hline Quality standard $^{\mathbf{a}}$ & $\mathbf{C P}$ & $\begin{array}{c}\text { ADF } \\
(\mathbf{D M} \text { \% })\end{array}$ & $\begin{array}{c}\text { NDF } \\
(\mathbf{D M} \text { \% })\end{array}$ & RFV $^{\mathbf{b}}$ \\
\hline Prime & $>19$ & $<31$ & $<40$ & $>\mathbf{1 5 1}$ \\
\hline $\mathbf{1}$ & $17-19$ & $31-40$ & $40-46$ & $\mathbf{1 5 1}-\mathbf{1 2 5}$ \\
\hline $\mathbf{2}$ & $14-16$ & $36-40$ & $47-53$ & $\mathbf{1 2 4}-\mathbf{1 0 4}$ \\
\hline $\mathbf{3}$ & $11-13$ & $41-42$ & $54-60$ & $\mathbf{1 0 2}-\mathbf{8 7}$ \\
\hline $\mathbf{4}$ & $8-10$ & $43-45$ & $61-65$ & $\mathbf{8 5}-\mathbf{7 5}$ \\
\hline $\mathbf{5}$ & $<\mathbf{8}$ & $>\mathbf{4 5}$ & $>\mathbf{6 5}$ & $<\mathbf{7 5}$ \\
\hline
\end{tabular}

${ }^{a}$ Standard assigned by Hay Market Task Force of American Forage and Grassland Council;

${ }^{\mathrm{b}}$ Relative Feed Value (RFV) - Reference hay of 100 RFV contains $41 \%$ ADF \& NDF and 53\% N, Okunade et al., (2014). 
Table.2 Chemical compositions, fiber fractions, and condensed tannins of the experimental rations

\begin{tabular}{|c|c|c|c|c|c|c|c|c|c|c|c|}
\hline \multirow[t]{2}{*}{ Treatments } & \multicolumn{7}{|c|}{ Chemical composition (as DM basis) } & \multicolumn{3}{|c|}{ Fiber fractions } & \multirow[t]{2}{*}{ CT } \\
\hline & $\mathbf{C P}$ & $\mathbf{C F}$ & Fat & NFE & Ash & DM & $\mathbf{O M}$ & NDF & ADF & ADL & \\
\hline $\mathbf{T 1}$ & $\begin{array}{l}11.35 \\
\pm 0.08^{\mathrm{d}}\end{array}$ & $\begin{array}{l}27.64 \\
\pm 0.6^{\mathrm{a}}\end{array}$ & $\begin{array}{c}2.45 \\
\pm 0.08^{\mathrm{a}}\end{array}$ & $\begin{array}{l}48.15 \\
\pm 0.82^{\mathrm{a}}\end{array}$ & $\begin{array}{c}10.41 \\
\pm 0.98^{\mathrm{e}}\end{array}$ & $\begin{array}{l}90.00 \\
\pm 0.15^{c}\end{array}$ & $\begin{array}{l}89.70 \\
\pm 0.14^{\mathrm{a}}\end{array}$ & $\begin{array}{l}33.50 \\
\pm 0.33^{\mathrm{e}}\end{array}$ & $\begin{array}{l}19.80 \\
\pm 0.75^{\mathrm{f}}\end{array}$ & $\begin{array}{c}10.80 \\
\pm 0.82^{\mathrm{a}}\end{array}$ & Nil \\
\hline $\mathbf{T} 2$ & $\begin{array}{c}12.84 \\
\pm 0.02^{\mathrm{b}}\end{array}$ & $\begin{array}{c}25.03 \\
\pm 0.42^{\text {c }}\end{array}$ & $\begin{array}{c}1.40 \\
\pm 0.04^{\mathrm{c}}\end{array}$ & $\begin{array}{c}35.3 \\
\pm 0.33^{\mathrm{f}}\end{array}$ & $\begin{array}{l}25.43 \\
\pm 0.32^{\mathrm{a}}\end{array}$ & $\begin{array}{l}92.42 \\
\pm 0.25^{\mathrm{a}}\end{array}$ & $\begin{array}{c}74.84 \\
\pm 0.42^{\mathrm{e}}\end{array}$ & $\begin{array}{l}55.70 \\
\pm 0.61^{\text {a }}\end{array}$ & $\begin{array}{l}40.45 \\
\pm 0.32^{\mathrm{a}}\end{array}$ & $\begin{array}{c}14.50 \\
\pm 0.77^{\mathrm{ab}}\end{array}$ & $\begin{array}{c}9.33 \\
\pm 0.002^{\mathrm{a}}\end{array}$ \\
\hline T3 & $\begin{array}{r}13.75 \\
\pm 0.04^{\mathrm{a}}\end{array}$ & $\begin{array}{c}22.20 \\
\pm 0.25^{\mathrm{d}}\end{array}$ & $\begin{array}{c}1.80 \\
\pm 0.05^{\mathrm{b}}\end{array}$ & $\begin{array}{c}38.45 \\
\pm 0.32^{\mathrm{e}}\end{array}$ & $\begin{array}{r}23.80 \\
\pm 0.36^{\mathrm{b}}\end{array}$ & $\begin{array}{l}92.53 \\
\pm 0.30^{\mathrm{a}}\end{array}$ & $\begin{array}{c}76.20 \\
\pm 0.32^{\mathrm{d}}\end{array}$ & $\begin{array}{r}52.56 \\
\pm 0.52^{\mathrm{b}}\end{array}$ & $\begin{array}{c}35.31 \\
\pm 0.22^{\mathrm{b}}\end{array}$ & $\begin{array}{c}12.38 \\
\pm 0.77^{\mathrm{b}}\end{array}$ & $\begin{array}{c}1.89 \\
\pm 0.005^{\mathrm{d}}\end{array}$ \\
\hline T4 & $\begin{array}{r}12.60 \\
\pm 0.03^{b}\end{array}$ & $\begin{array}{c}26.34 \\
\pm 0.58^{b}\end{array}$ & $\begin{array}{c}1.93 \\
\pm 0.06^{\mathrm{b}}\end{array}$ & $\begin{array}{l}41.23 \\
\pm 0.36^{d}\end{array}$ & $\begin{array}{c}17.90 \\
\pm 0.42^{\mathrm{c}}\end{array}$ & $\begin{array}{c}91.26 \\
\pm 0.22^{\mathrm{b}}\end{array}$ & $\begin{array}{l}82.27 \\
\pm 0.14^{\mathrm{c}}\end{array}$ & $\begin{array}{l}44.60 \\
\pm 0.72^{\mathrm{c}}\end{array}$ & $\begin{array}{c}30.13 \\
\pm 0.42^{\mathrm{c}}\end{array}$ & $\begin{array}{c}12.65 \\
\pm 0.79^{\mathrm{ab}}\end{array}$ & $\begin{array}{c}4.66 \\
\pm 0.006^{\mathrm{b}}\end{array}$ \\
\hline T5 & $\begin{array}{l}12.01 \\
\pm 0.05^{\mathrm{c}}\end{array}$ & $\begin{array}{c}24.92 \\
\pm 0.32^{c}\end{array}$ & $\begin{array}{c}2.13 \\
\pm 0.07^{\mathrm{a}}\end{array}$ & $\begin{array}{l}43.81 \\
\pm 0.51^{\mathrm{c}}\end{array}$ & $\begin{array}{l}17.13 \\
\pm 0.45^{\mathrm{c}}\end{array}$ & $\begin{array}{c}91.31 \\
\pm 0.20^{\mathrm{b}}\end{array}$ & $\begin{array}{l}82.95 \\
\pm 0.02^{\mathrm{c}}\end{array}$ & $\begin{array}{l}43.03 \\
\pm 0.66^{c}\end{array}$ & $\begin{array}{l}27.56 \\
\pm 0.35^{\mathrm{d}}\end{array}$ & $\begin{array}{c}11.59 \\
\pm 0.80^{\mathrm{ab}}\end{array}$ & $\begin{array}{c}0.95 \\
\pm 0.007^{\mathrm{d}}\end{array}$ \\
\hline T6 & $\begin{array}{c}12.71 \\
\pm 0.05^{\mathrm{b}}\end{array}$ & $\begin{array}{c}26.99 \\
\pm 0.55^{\mathrm{ab}}\end{array}$ & $\begin{array}{c}2.19 \\
\pm 0.06^{\mathrm{a}}\end{array}$ & $\begin{array}{r}43.95 \\
\pm 0.75^{b}\end{array}$ & $\begin{array}{c}14.16 \\
\pm 0.68^{\mathrm{d}}\end{array}$ & $\begin{array}{l}90.63 \\
\pm 0.18^{\mathrm{c}}\end{array}$ & $\begin{array}{c}85.99 \\
\pm 0.15^{\mathrm{b}}\end{array}$ & $\begin{array}{l}39.06 \\
\pm 0.53^{d}\end{array}$ & $\begin{array}{r}24.96 \\
\pm 0.54^{\mathrm{e}}\end{array}$ & $\begin{array}{c}11.73 \\
\pm 0.81^{\mathrm{a}}\end{array}$ & $\begin{array}{c}2.33 \\
\pm 0.008^{c}\end{array}$ \\
\hline T7 & $11.95 \pm 0.07^{\mathrm{c}}$ & $\begin{array}{c}25.88 \\
\pm 0.44^{b}\end{array}$ & $\begin{array}{c}2.39 \\
\pm 0.08^{\mathrm{a}}\end{array}$ & $\begin{array}{c}45.92 \\
\pm 0.63^{\mathrm{b}}\end{array}$ & $\begin{array}{c}13.86 \\
\pm 0.82^{d}\end{array}$ & $\begin{array}{l}90.66 \\
\pm 0.17^{\mathrm{c}}\end{array}$ & $\begin{array}{c}86.33 \\
\pm 0.17^{\mathrm{b}}\end{array}$ & $\begin{array}{c}38.27 \\
\pm 0.42^{\mathrm{d}}\end{array}$ & $\begin{array}{l}23.68 \\
\pm 0.65^{\mathrm{e}}\end{array}$ & $\begin{array}{l}11.20 \\
\pm 0.82^{\mathrm{a}}\end{array}$ & $\begin{array}{c}0.47 \\
\pm 0.009^{\mathrm{d}}\end{array}$ \\
\hline $\begin{array}{l}\text { a,b,c,d,e,f me } \\
\text { CP: crude p } \\
\text { detergent fibe } \\
\text { halimus, T3: }\end{array}$ & ns in the same & row with & lifferent & uperscri] & ts differ $s$ & ignifican & $y$ at $P<0$ & 05. & & & 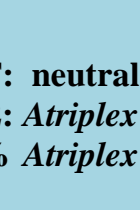 \\
\hline
\end{tabular}

Table.3 Macro \& Micro - mineral composition of specific tree and shrubs species (as DM basis)

\begin{tabular}{|c|c|c|c|c|c|c|c|c|}
\hline \multirow{2}{*}{ Treatments } & \multicolumn{5}{|c|}{ Macro-mineral (ppm) } & \multicolumn{3}{c|}{ Micro-mineral (ppm) } \\
\cline { 2 - 9 } & Na & Ca & K & P & Mg & Fe & Mn & Zn \\
\hline T1 & $4210.67^{\mathrm{a}}$ & $2564.11^{\mathrm{e}}$ & $10889.92^{\mathrm{e}}$ & $1015.05^{\mathrm{e}}$ & $515.65^{\mathrm{e}}$ & $471.20^{\mathrm{b}}$ & $31.94^{\mathrm{c}}$ & $30.38^{\mathrm{b}}$ \\
\hline T2 & $37008.01^{\mathrm{a}}$ & $44020.02^{\mathrm{a}}$ & $12961.01^{\mathrm{c}}$ & $2030.02^{\mathrm{d}}$ & $1750.22^{\mathrm{d}}$ & $544.76^{\mathrm{a}}$ & $43.09^{\mathrm{a}}$ & $35.61^{\mathrm{a}}$ \\
\hline T3 & $9037.88^{\mathrm{f}}$ & $2528.05^{\mathrm{e}}$ & $14541.77^{\mathrm{b}}$ & $1031.80^{\mathrm{e}}$ & $531.83^{\mathrm{e}}$ & $215.42^{\mathrm{e}}$ & $10.87^{\mathrm{e}}$ & $23.05^{\mathrm{d}}$ \\
\hline T4 & $28109.34^{\mathrm{b}}$ & $26292.17^{\mathrm{b}}$ & $31366.98^{\mathrm{a}}$ & $2712.54^{\mathrm{b}}$ & $2212.24^{\mathrm{b}}$ & $507.98^{\mathrm{a}}$ & $37.61^{\mathrm{b}}$ & $33.00^{\mathrm{a}}$ \\
\hline T5 & $14124.28^{\mathrm{e}}$ & $5546.19^{\mathrm{f}}$ & $12715.85^{\mathrm{c}}$ & $2213.43^{\mathrm{c}}$ & $1773.45^{\mathrm{c}}$ & $343.31^{\mathrm{d}}$ & $21.41^{\mathrm{d}}$ & $31.61^{\mathrm{b}}$ \\
\hline T6 & $23660.00^{\mathrm{c}}$ & $17428.09^{\mathrm{c}}$ & $11407.69^{\mathrm{d}}$ & $3053.79^{\mathrm{a}}$ & $2250.70^{\mathrm{a}}$ & $489.59^{\mathrm{b}}$ & $34.66^{\mathrm{b}}$ & $31.69^{\mathrm{b}}$ \\
\hline T7 & $16667.47^{\mathrm{d}}$ & $7055.09^{\mathrm{d}}$ & $11802.88^{\mathrm{d}}$ & $2804.24^{\mathrm{b}}$ & $2322.20^{\mathrm{b}}$ & $407.26^{\mathrm{c}}$ & $22.94^{\mathrm{d}}$ & $28.55^{\mathrm{c}}$ \\
\hline
\end{tabular}

a,b,c,d,e,f,g Means in the same row with different superscripts differ significantly at $P<0.05$.

Na: Sodium, Ca: Calcium, K: Potassium, P: Phosphor, Fe: Ferric, Mn: Manganese, Ze: Zinc, T1: Berseem Hay, T2: Atriplex halimus, T3: Atriplex nummularia, T4: 50\% berseem hay $+50 \%$ Atriplex halimus, T5: 50\% berseem hay $+50 \%$ Atriplex nummularia, T6: 75\% berseem hay $+25 \%$ Atriplex Halimus, T7: 75\% berseem hay $+25 \%$ Atriplex nummularia. 
Table.4 Dry matter digestibility, dry matter intake, metabolizable energy, organic matter digestibility, and relative feed value prediction of selected browses

\begin{tabular}{|c|c|c|c|c|c|c|}
\hline Treatments & $\begin{array}{c}\text { DMD } \\
(\boldsymbol{\%})\end{array}$ & $\begin{array}{c}\text { DMI } \\
(\boldsymbol{\%} \text { of } \mathbf{B W})\end{array}$ & $\begin{array}{c}\text { OMD } \\
(\boldsymbol{\%})\end{array}$ & $\begin{array}{c}\text { ME } \\
(\mathbf{M J} / \mathbf{K} \mathbf{D M})\end{array}$ & RFV & $\begin{array}{c}\text { Quality } \\
\text { standard }\end{array}$ \\
\hline T1 & $73.48^{\mathrm{a}}$ & $3.58^{\mathrm{a}}$ & $54.27^{\mathrm{b}}$ & $7.99^{\mathrm{a}}$ & $203.92^{\mathrm{a}}$ & Prime \\
\hline T2 & $57.38^{\mathrm{f}}$ & $2.15^{\mathrm{d}}$ & $47.65^{\mathrm{e}}$ & $6.81^{\mathrm{d}}$ & $123.37^{\mathrm{g}}$ & $\mathbf{2}$ \\
\hline T3 & $61.93^{\mathrm{e}}$ & $2.28^{\mathrm{d}}$ & $49.11^{\mathrm{d}}$ & $7.04^{\mathrm{c}}$ & $141.20^{\mathrm{e}}$ & $\mathbf{1}$ \\
\hline T4 & $65.42^{\mathrm{d}}$ & $2.69^{\mathrm{c}}$ & $61.67^{\mathrm{a}}$ & $7.43^{\mathrm{b}}$ & $136.42^{\mathrm{f}}$ & $\mathbf{1}$ \\
\hline T5 & $67.43^{\mathrm{c}}$ & $2.79^{\mathrm{c}}$ & $51.45^{\mathrm{c}}$ & $7.48^{\mathrm{b}}$ & $145.77^{\mathrm{d}}$ & $\mathbf{1}$ \\
\hline T6 & $69.46^{\mathrm{b}}$ & $3.07^{\mathrm{b}}$ & $53.06^{\mathrm{b}}$ & $7.75^{\mathrm{a}}$ & $165.29^{\mathrm{c}}$ & Prime \\
\hline T7 & $\mathbf{7 0 . 4 5}^{\mathbf{b}}$ & $\mathbf{3 . 1 4}^{\mathbf{b}}$ & $\mathbf{6 1 . 1 1}^{\mathrm{a}}$ & $\mathbf{7 . 7 5}^{\mathrm{a}}$ & $\mathbf{1 7 1 . 2 4}^{\mathbf{b}}$ & Prime \\
\hline
\end{tabular}

a,b,c,d,e,f,g Means in the same row with different superscripts differ significantly at $P<0.05$.

DMD: Dry matter digestibility (\%), OMD: Organic matter digestibility, DMI: Dry matter intake (\% of body weight), ME: Metabolisable energy, RFV = Relative feed value, T1: Berseem Hay, T2: Atriplex halimus, T3: Atriplex nummularia T4: 50\% berseem hay $+50 \%$ Atriplex halimus, T5: 50\% berseem hay $+50 \%$ Atriplex nummularia, T6: $75 \%$ berseem hay $+25 \%$ Atriplex halimus, $77: 75 \%$ berseem hay $+25 \%$ Atriplex nummularia

Table.5 Accumulative gas production and estimated parameters for a variety of roughages incubated with rumen fluid in vitro

\begin{tabular}{|c|c|c|c|c|c|c|c|c|c|}
\hline \multirow[t]{2}{*}{$\begin{array}{c}\text { Treatm } \\
\text { ents }\end{array}$} & \multicolumn{5}{|c|}{$\begin{array}{l}\text { Accumulative gas production (Incubation } \\
\text { times, h) }\end{array}$} & \multicolumn{4}{|c|}{ Estimated parameters } \\
\hline & $3 \mathbf{h}$ & $6 \mathrm{~h}$ & $12 \mathrm{~h}$ & $24 h$ & $48 \mathrm{~h}$ & c & $\mathbf{A}$ & b & $\mathbf{a}+\mathbf{b}$ \\
\hline $\mathbf{T 1}$ & $\begin{array}{c}6.90 \\
\pm 0.07^{\mathrm{a}}\end{array}$ & $\begin{array}{l}15.50 \\
\pm 0.22^{\mathrm{a}}\end{array}$ & $\begin{array}{l}25.71 \\
\pm 0.63^{\mathrm{a}}\end{array}$ & $\begin{array}{l}37.80 \\
\pm 0.47^{\text {a }}\end{array}$ & $\begin{array}{l}47.60 \\
\pm 0.45^{\mathrm{a}}\end{array}$ & $\begin{array}{c}0.070 \\
\pm 0.006^{\mathrm{a}}\end{array}$ & $\begin{array}{c}3.60 \\
\pm 0.09^{\mathrm{a}}\end{array}$ & $\begin{array}{c}45.04 \pm \\
0.87^{\mathrm{e}}\end{array}$ & $\begin{array}{l}48.49 \\
\pm 0.78^{\mathrm{a}}\end{array}$ \\
\hline $\mathbf{T} 2$ & $\begin{array}{c}4.20 \\
\pm 0.03^{\mathrm{c}}\end{array}$ & $\begin{array}{c}8.60 \\
\pm 0.87^{\mathrm{e}}\end{array}$ & $\begin{array}{l}18.90 \\
\pm 0.76^{\text {e }}\end{array}$ & $\begin{array}{l}28.50 \\
\pm 0.62^{\mathrm{e}}\end{array}$ & $\begin{array}{l}32.70 \\
\pm 0.63^{\mathrm{e}}\end{array}$ & $\begin{array}{c}0.052 \\
\pm 0.007^{\mathrm{a}}\end{array}$ & $\begin{array}{c}2.20 \\
\pm 0.04^{\mathrm{e}}\end{array}$ & $\begin{array}{l}33.04 \\
\pm 0.33^{\text {f }}\end{array}$ & $\begin{array}{r}35.24 \\
\pm 0.35^{\mathrm{g}}\end{array}$ \\
\hline T3 & $\begin{array}{c}5.80 \\
\pm 0.06^{\mathrm{b}}\end{array}$ & $\begin{array}{l}10.25 \\
\pm 0.45^{\mathrm{d}}\end{array}$ & $\begin{array}{l}20.20 \\
\pm 0.85^{\mathrm{d}}\end{array}$ & $\begin{array}{c}29.80 \pm \\
0.65^{\mathrm{d}}\end{array}$ & $\begin{array}{l}35.90 \\
\pm 0.68^{\mathrm{d}}\end{array}$ & $\begin{array}{c}0.061 \\
\pm 0.008^{\mathrm{b}}\end{array}$ & $\begin{array}{c}2.50 \\
\pm 0.04^{\mathrm{d}}\end{array}$ & $\begin{array}{l}37.01 \\
\pm 0.53^{\mathrm{e}}\end{array}$ & $\begin{array}{l}39.51 \\
\pm 0.52^{f}\end{array}$ \\
\hline T4 & $\begin{array}{c}5.55 \\
\pm 0.05^{\mathrm{b}}\end{array}$ & $\begin{array}{c}12.05 \\
\pm 0.65^{\mathrm{c}}\end{array}$ & $\begin{array}{l}22.31 \\
\pm 0.75^{\mathrm{c}}\end{array}$ & $\begin{array}{l}33.15 \\
\pm 0.45^{\mathrm{c}}\end{array}$ & $\begin{array}{c}41.15 \\
\pm 0.75^{c}\end{array}$ & $\begin{array}{c}0.065 \pm 0 \\
007^{\mathrm{a}}\end{array}$ & $\begin{array}{c}2.80 \\
\pm 0.03^{\mathrm{c}}\end{array}$ & $\begin{array}{c}39.04 \\
\pm 0.65^{\mathrm{d}}\end{array}$ & $\begin{array}{l}41.84 \\
\pm 0.48^{\mathrm{e}}\end{array}$ \\
\hline T5 & $\begin{array}{c}6.35 \\
\pm 0.05^{\mathrm{a}}\end{array}$ & $\begin{array}{c}12.88 \\
\pm 0.75^{\mathrm{c}}\end{array}$ & $\begin{array}{l}24.46 \\
\pm 0.92^{\mathrm{b}}\end{array}$ & $\begin{array}{l}33.80 \\
\pm 0.61^{\mathrm{c}}\end{array}$ & $\begin{array}{c}41.75 \\
\pm 0.78^{c}\end{array}$ & $\begin{array}{c}0.066 \\
\pm 0.008^{\mathrm{a}}\end{array}$ & $\begin{array}{c}3.12 \\
\pm 0.05^{\mathrm{b}}\end{array}$ & $\begin{array}{c}41.03 \\
\pm 0.72^{c}\end{array}$ & $\begin{array}{l}44.15 \\
\pm 0.65^{\circ}\end{array}$ \\
\hline T6 & $\begin{array}{c}6.23 \\
\pm 0.04^{\mathrm{a}}\end{array}$ & $\begin{array}{c}13.78 \\
\pm 0.42^{b}\end{array}$ & $\begin{array}{l}24.01 \\
\pm 0.82^{b}\end{array}$ & $\begin{array}{c}35.48 \\
\pm 0.53^{\mathrm{b}}\end{array}$ & $\begin{array}{c}43.88 \\
\pm 0.76^{b}\end{array}$ & $\begin{array}{c}0.068 \\
\pm 0.008^{\mathrm{a}}\end{array}$ & $\begin{array}{c}3.25 \\
\pm 0.07^{\mathrm{ab}}\end{array}$ & $\begin{array}{c}42.04 \\
\pm 0.80^{\mathrm{b}}\end{array}$ & $\begin{array}{r}45.29 \\
\pm 0.43^{\circ}\end{array}$ \\
\hline T7 & $\begin{array}{c}6.63 \pm 0 \\
87^{\mathrm{a}}\end{array}$ & $\begin{array}{c}14.19 \\
\pm 0.33^{\mathrm{b}}\end{array}$ & $\begin{array}{c}24.33 \\
\pm 0.66^{\mathrm{b}}\end{array}$ & $\begin{array}{c}35.80 \\
\pm 0.57^{\mathrm{b}}\end{array}$ & $\begin{array}{c}44.68 \\
\pm 0.62^{b}\end{array}$ & $\begin{array}{c}0.069 \pm 0 \\
007^{\mathrm{a}}\end{array}$ & $\begin{array}{c}3.45 \\
\pm 0.03^{\mathrm{a}}\end{array}$ & $\begin{array}{c}43.03 \\
\pm 0.85^{b}\end{array}$ & $\begin{array}{l}46.63 \\
\pm 0.65^{\mathrm{b}}\end{array}$ \\
\hline ,c,d, & ean & San & 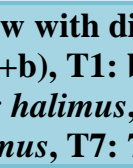 & 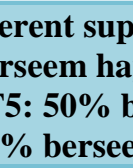 & 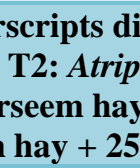 & -5 & & & - \\
\hline
\end{tabular}


Table.6 Growth performance and feed efficiency of Barki lambs fed experimental rations

\begin{tabular}{|c|c|c|c|c|c|c|c|}
\hline \multirow[t]{2}{*}{ Items } & \multicolumn{7}{|c|}{ Treatments } \\
\hline & T1 & $\mathbf{T 2}$ & T3 & T4 & T5 & T6 & $\mathbf{T 7}$ \\
\hline \multicolumn{8}{|l|}{ Feed intake } \\
\hline$\overline{\text { Roughage (g) }}$ & $\begin{array}{c}400 \\
\pm 0.88^{\mathrm{a}}\end{array}$ & $\begin{array}{c}150 \\
\pm 0.33^{\mathrm{f}}\end{array}$ & $\begin{array}{c}200 \\
\pm 0.42^{\mathrm{e}}\end{array}$ & $\begin{array}{c}250 \\
\pm 0.55^{\mathrm{d}}\end{array}$ & $\begin{array}{c}300 \\
\pm 0.64^{\mathrm{c}}\end{array}$ & $\begin{array}{c}300 \\
\pm 0.66^{c}\end{array}$ & $\begin{array}{c}350 \\
\pm 0.75^{\mathrm{b}}\end{array}$ \\
\hline $\operatorname{CFM}(\mathrm{g})$ & $\begin{array}{c}800 \\
\pm 0.65^{\mathrm{a}}\end{array}$ & $\begin{array}{c}600 \\
\pm 0.55^{\mathrm{d}}\end{array}$ & $\begin{array}{c}700 \pm 0 \\
55^{\mathrm{c}}\end{array}$ & $\begin{array}{c}750 \\
\pm 0.60^{\mathrm{b}}\end{array}$ & $\begin{array}{c}750 \pm 0 . \\
60^{\mathrm{b}}\end{array}$ & $\begin{array}{c}800 \\
\pm 0.65^{\mathrm{a}}\end{array}$ & $\begin{array}{c}800 \\
\pm 0.65^{\mathrm{a}}\end{array}$ \\
\hline TDMI (g/h/d) & $\begin{array}{c}1200 \\
\pm 2.12^{\mathrm{a}}\end{array}$ & $\begin{array}{c}750 \\
\pm 0.18^{\mathrm{g}}\end{array}$ & $\begin{array}{c}900 \\
\pm 0.36^{\mathrm{f}}\end{array}$ & $\begin{array}{c}1000 \\
\pm 0.16^{\mathrm{e}}\end{array}$ & $\begin{array}{c}1050 \\
\pm 1.24^{\mathrm{d}}\end{array}$ & $\begin{array}{c}1100 \\
\pm 1.22^{\mathrm{c}}\end{array}$ & $\begin{array}{c}1150 \\
\pm 1.15^{\mathrm{b}}\end{array}$ \\
\hline DMI (g/kg $\left.{ }^{\text {w0.75}}\right)$ & $\begin{array}{c}95 \\
\pm 2.11^{\mathrm{a}}\end{array}$ & $\begin{array}{c}60 \\
\pm 1.01^{\mathrm{g}}\end{array}$ & $\begin{array}{c}65 \\
\pm 1.21^{\mathrm{f}}\end{array}$ & $\begin{array}{c}75 \\
\pm 1.24^{\mathrm{e}}\end{array}$ & $\begin{array}{c}80 \\
\pm 1.55^{\mathrm{d}}\end{array}$ & $\begin{array}{c}85 \\
\pm 1.78^{c}\end{array}$ & $90 \pm 2.01^{b}$ \\
\hline TOMI (g/h/d) & $\begin{array}{c}1100 \\
\pm 1.25^{\mathrm{a}}\end{array}$ & $\begin{array}{c}750 \\
\pm 0.55^{\mathrm{g}}\end{array}$ & $\begin{array}{c}850 \\
\pm 0.60^{\mathrm{f}}\end{array}$ & $\begin{array}{c}900 \\
\pm 0.75^{\mathrm{e}}\end{array}$ & $\begin{array}{c}950 \\
\pm 0.80^{\mathrm{d}}\end{array}$ & $\begin{array}{c}1000 \\
\pm 0.95^{\mathrm{c}}\end{array}$ & $\begin{array}{c}1050 \\
\pm 1.85^{\mathrm{b}}\end{array}$ \\
\hline CP intake (g) & $\begin{array}{c}140 \\
\pm 0.45^{\mathrm{a}}\end{array}$ & $\begin{array}{c}75 \\
\pm 0.48^{\mathrm{g}} \\
\end{array}$ & $\begin{array}{c}95 \\
\pm 0.66^{\mathrm{f}}\end{array}$ & $\begin{array}{c}100 \\
\pm 0.72^{\mathrm{e}}\end{array}$ & $\begin{aligned} & 115 \\
& \pm 0.65^{\mathrm{d}}\end{aligned}$ & $\begin{array}{c}122 \\
\pm 0.85^{\mathrm{c}}\end{array}$ & $\begin{array}{c}135 \\
\pm 0.77^{\mathrm{b}}\end{array}$ \\
\hline \multicolumn{8}{|l|}{ Growth performance } \\
\hline$\overline{\text { No. of lambs }}$ & 5 & 5 & 5 & 5 & 5 & 5 & 5 \\
\hline Feeding period (week) & 18 & 18 & 18 & 18 & 18 & 18 & 18 \\
\hline Initial weight (kg) & $\begin{array}{l}12.08 \\
\pm 0.46\end{array}$ & $\begin{array}{l}12.12 \\
\pm 0.17\end{array}$ & $\begin{array}{l}12.32 \\
\pm 0.29\end{array}$ & $\begin{array}{l}12.32 \\
\pm 0.29\end{array}$ & $\begin{array}{l}12.02 \\
\pm 0.06\end{array}$ & $\begin{array}{l}12.32 \\
\pm 0.29\end{array}$ & $\begin{array}{l}12.28 \\
\pm 0.11\end{array}$ \\
\hline ight (kg) & $\begin{array}{c}33.46 \\
\pm 0.48^{\mathrm{a}}\end{array}$ & $\begin{array}{c}22.20 \\
\pm 0.43^{\mathrm{g}}\end{array}$ & $\begin{array}{l}26.18 \\
\pm 0.46^{\mathrm{f}}\end{array}$ & $\begin{array}{l}28.07 \\
\pm 0.46^{\mathrm{e}}\end{array}$ & $\begin{array}{r}29.66 \\
\pm 0.53^{\mathrm{e}}\end{array}$ & $\begin{array}{c}30.97 \\
\pm 0.46^{c}\end{array}$ & $\begin{array}{c}31.81 \\
\pm 0.48^{\mathrm{b}}\end{array}$ \\
\hline Total gain (kg) & $\begin{array}{c}21.42 \\
\pm 0.13^{\mathrm{a}}\end{array}$ & $\begin{array}{c}10.08 \\
\pm 0.27^{\mathrm{e}}\end{array}$ & $\begin{array}{c}13.86 \\
\pm 0.32^{\mathrm{d}}\end{array}$ & $\begin{array}{c}10.71 \\
\pm 0.32^{\mathrm{e}}\end{array}$ & $\begin{array}{c}15.12 \\
\pm 0.53^{\mathrm{c}}\end{array}$ & $\begin{array}{c}18.65 \\
\pm 0.32^{b}\end{array}$ & $\begin{array}{c}19.53 \\
\pm 0.42^{\mathrm{b}}\end{array}$ \\
\hline Daily body gain (g) & $\begin{array}{c}170 \\
\pm 0.01^{\mathrm{a}}\end{array}$ & $\begin{array}{l}80.00 \\
\pm 0.02^{\text {f }}\end{array}$ & $\begin{array}{l}110.00 \\
\pm 0.04^{\mathrm{e}}\end{array}$ & $\begin{array}{l}125.00 \\
\pm 0.03^{\mathrm{d}}\end{array}$ & $\begin{array}{l}140.00 \\
\pm 0.04^{\mathrm{c}}\end{array}$ & $\begin{array}{l}148.00 \\
\pm 0.03^{\mathrm{c}}\end{array}$ & $\begin{array}{l}155.00 \\
\pm 0.03^{\mathrm{b}}\end{array}$ \\
\hline $\begin{array}{l}\text { Feed conversion }(\mathrm{Kg} \\
\mathrm{CP} / \mathrm{Kg} \text { gain) }\end{array}$ & $\begin{array}{l}0.82 \pm \\
0.003^{b}\end{array}$ & $\begin{array}{l}0.94 \pm \\
0.007^{\mathrm{a}}\end{array}$ & $\begin{array}{l}0.86 \pm \\
0.005^{\mathrm{ab}}\end{array}$ & $\begin{array}{l}0.80 \pm \\
0.006^{b}\end{array}$ & $\begin{array}{l}0.82 \pm \\
0.003^{b}\end{array}$ & $\begin{array}{l}0.82 \pm \\
0.003^{b}\end{array}$ & $\begin{array}{l}0.87 \pm \\
0.006^{\mathrm{ab}}\end{array}$ \\
\hline \multicolumn{8}{|l|}{ Feed efficiency } \\
\hline Total feeding cost, LE & 3.39 & 2.33 & 2.24 & 2.77 & 2.79 & 3.08 & 3.12 \\
\hline $\begin{array}{l}\text { Price of daily gain, } \\
\text { LE }\end{array}$ & 11.05 & 6.56 & 6.82 & 7.15 & 10.01 & 7.67 & 10.46 \\
\hline $\begin{array}{l}\text { Economic efficiency } \\
\%\end{array}$ & 2.25 & 1.81 & 2.04 . & 1.58 & 2.58 & 1.49 & 2.35 \\
\hline \multicolumn{8}{|c|}{$\begin{array}{l}\text { a,b,c,d,: Means in the same row with different superscripts differ significantly at } P<0.05 \text {. } \\
\text { T1: berseem hay, T2: Atriplex halimus, T3: Atriplex nummularia, T4: } 50 \% \text { berseem hay }+50 \% \text { Atriplex } \\
\text { halimus, T5: } 50 \% \text { berseem hay }+50 \% \text { Atriplex nummularia, T6: } 75 \% \text { berseem hay }+25 \% \text { Atriplex } \\
\text { halimus, T7: } 75 \% \text { berseem hay }+25 \% \text { Atriplex nummularia, TDMI: total dry matter intake, TOMI: total } \\
\text { organic matter intake, CFM: concentrate feed mixture. } \\
\text { Total price for feeds calculated according to the price of different ingredients available in Egypt. } \\
\text { 1- The local market prices were; } 4500 \text { LE for one ton CFM, } 500 \text { LE for one ton Atriplex halimus, } 500 \text { LE } \\
\text { for one ton Atriplex nummularia, } 3000 \text { LE for one-ton berseem hay and } 65 \text { L.E. price for one Kg live } \\
\text { body weight of lambs. } \\
\text { 2- Economic efficiency (EE) = net profile / total feeding cost, LE. }\end{array}$} \\
\hline
\end{tabular}


Table.7 Effect of feeding experimental rations for Barki lambs on some blood serum parameters

\begin{tabular}{|l|c|c|c|c|c|c|c|}
\hline \multirow{2}{*}{ Items } & \multicolumn{7}{|c|}{ Treatments } \\
\cline { 2 - 9 } & T1 & T2 & T3 & T4 & T5 & T6 & T7 \\
\hline Total protein, g/dl & 8.11 & 6.42 & 7.06 & 6.55 & 6.82 & 7.10 & 7.45 \\
& $\pm 0.50^{\mathrm{a}}$ & $\pm 0.34^{\mathrm{b}}$ & $\pm 0.46^{\mathrm{ab}}$ & $\pm 0.51^{\mathrm{ab}}$ & $\pm 0.51^{\mathrm{ab}}$ & $\pm 0.25^{\mathrm{ab}}$ & $\pm 0.25^{\mathrm{ab}}$ \\
\hline Albumin, g/dl & 4.61 & 3.50 & 3.87 & 3.94 & 3.70 & 3.63 & 3.90 \\
& $\pm 0.38^{\mathrm{a}}$ & $\pm 0.19^{\mathrm{b}}$ & $\pm 0.23^{\mathrm{ab}}$ & $\pm 0.23^{\mathrm{ab}}$ & $\pm 0.23^{\mathrm{ab}}$ & $\pm 0.29^{\mathrm{ab}}$ & $\pm 0.29^{\mathrm{ab}}$ \\
\hline Globulin, g/dl & 3.60 & 3.19 & 3.35 & 3.20 & 3.30 & 3.46 & 3.56 \\
& $\pm 0.14^{\mathrm{a}}$ & $\pm 0.18^{\mathrm{b}}$ & $\pm 0.24^{\mathrm{ab}}$ & $\pm 0.29^{\mathrm{ab}}$ & $\pm 0.29^{\mathrm{ab}}$ & $\pm 0.10^{\mathrm{ab}}$ & $\pm 0.10^{\mathrm{a}}$ \\
\hline A/G ratio & 1.28 & 1.10 & 1.16 & 1.23 & 1.12 & 1.05 & 1.10 \\
& $\pm 0.07^{\mathrm{a}}$ & $\pm 0.05^{\mathrm{ab}}$ & $\pm 0.04^{\mathrm{ab}}$ & $\pm 0.07^{\mathrm{ab}}$ & $\pm 0.07^{\mathrm{ab}}$ & $\pm 0.10^{\mathrm{b}}$ & $\pm 0.10^{\mathrm{ab}}$ \\
\hline Urea-N, mg/dl & 23.62 & 19.99 & 22.13 & 23.20 & 21.50 & 23.19 & 24.10 \\
& $\pm 0.39^{\mathrm{a}}$ & $\pm 0.20^{\mathrm{c}}$ & $\pm 0.65^{\mathrm{b}}$ & $\pm 0.43^{\mathrm{ab}}$ & $\pm 0.43^{\mathrm{ab}}$ & $\pm 0.52^{\mathrm{ab}}$ & $\pm 0.52^{\mathrm{a}}$ \\
\hline Creatinine, mg/dl & 1.13 & 1.92 & 1.61 & 1.82 & 1.51 & 1.31 & 1.22 \\
& $\pm 0.11^{\mathrm{d}}$ & $\pm 0.12^{\mathrm{a}}$ & $\pm 0.18^{\mathrm{b}}$ & $\pm 0.10^{\mathrm{a}}$ & $\pm 0.10^{\mathrm{b}}$ & $\pm 0.12^{\mathrm{c}}$ & $\pm 0.12^{\mathrm{c}}$ \\
\hline AST, U/l & 26.05 & 33.49 & 31.44 & 30.48 & 29.18 & 30.10 & 28.15 \\
& $\pm 0.58^{\mathrm{d}}$ & $\pm 0.30^{\mathrm{a}}$ & $\pm 0.59^{\mathrm{ab}}$ & $\pm 0.52^{\mathrm{b}}$ & $\pm 0.52^{\mathrm{c}}$ & $\pm 0.48^{\mathrm{ab}}$ & $\pm 0.48^{\mathrm{c}}$ \\
\hline & 16.28 & 20.90 & 19.46 & 17.90 & 17.64 & 17.81 & 17.70 \\
ALT, U/l & $\pm 0.29^{\mathrm{d}}$ & $\pm 0.32^{\mathrm{a}}$ & $\pm 0.32^{\mathrm{b}}$ & $\pm 0.40^{\mathrm{c}}$ & $\pm 0.40^{\mathrm{c}}$ & $\pm 0.45^{\mathrm{c}}$ & $\pm 0.45^{\mathrm{c}}$ \\
\hline
\end{tabular}

Figure 1.Cumulative gas volume for a variety of roughages incubated with rumen fluid in vitro.

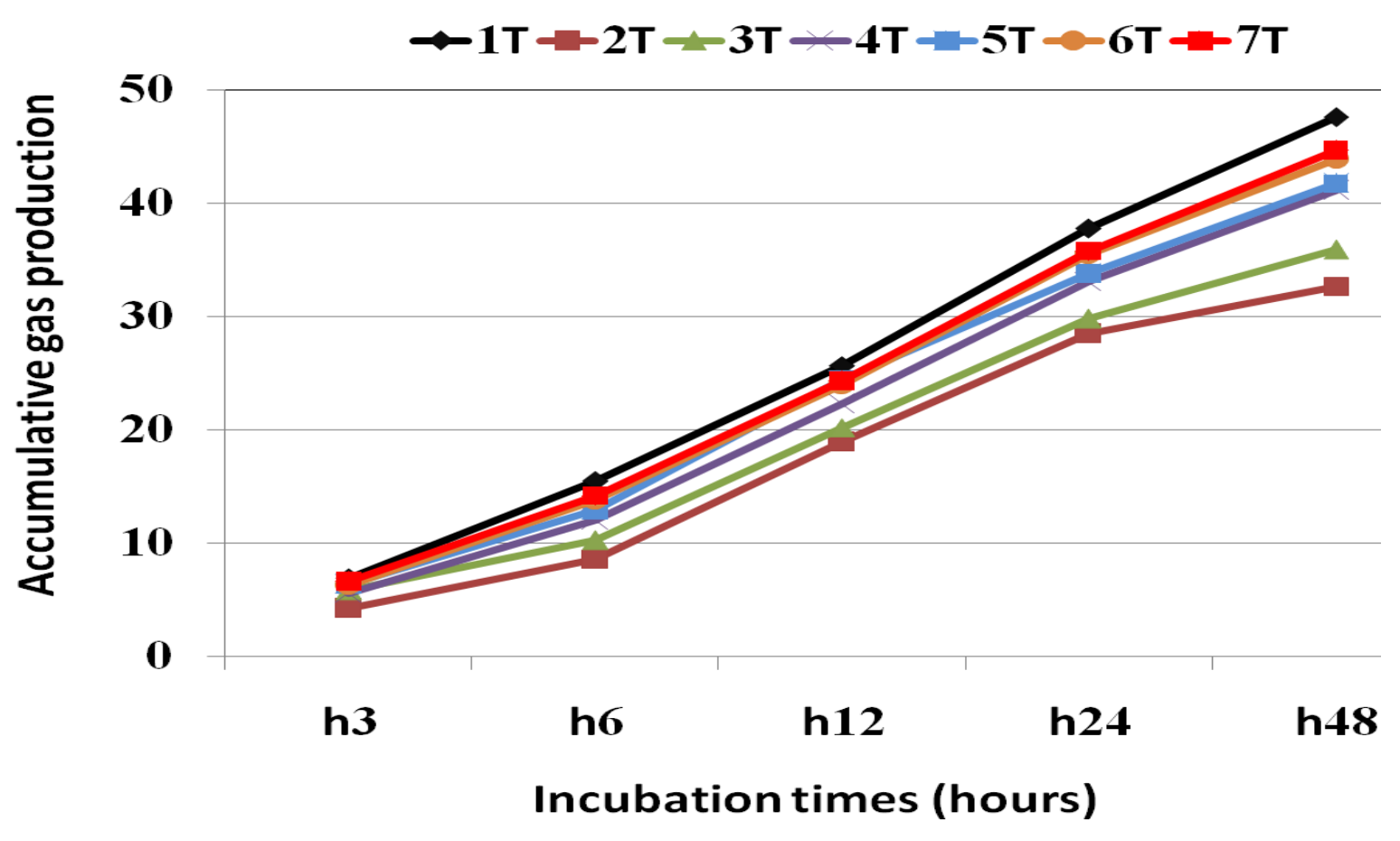


Concentrations of AST and ALT enzymes that conventionally used for diagnosing hepatic damage were higher with salt-tolerant shrubs groups, but the differences were significant $(P<0.05)$. Generally, the obtained results indicated that blood components measured showed slight variations due to the source of shrubs, as all levels were within the normal ranges reported by Silanikove et al., (1996).

In conclusion, the nutritional value of leaves and twigs for $A$. nummularia is better than $A$. halimus, and A. nummularia can replace up to $50 \%$ of $\mathrm{BH}$ without adverse effects on the consumption and digestion of dry matter. Fodder shrubs, especially the species of Atriplex , are known for their tolerance to drought and salinity. In semi-arid regions where lack of water resources limits $\mathrm{BH}$ production, these fodder bushes can use to replace partial $\mathrm{BH}$ in the small ruminant diet. A. nummularia are exotic species, while $A$. halimus is an indigenous species in the Mediterranean basin. Previous shrubs may be used in certain mixtures with concentrated feed mixtures to enhance the supply of livestock feed and to ensure an acceptable level of production in semi-arid conditions. Economic efficiency criteria supported justified a conclusion that favored the $50 \%$ AN (T5)than other treatments.

\section{References}

Abu-Zanat, M.M.W. 2005.Voluntary intake and digestibility of saltbush by sheep. AsianAustralasian Journal of Animal Sciences. 18(2): 214-220.

Aganga, A.A., Mthetho, J.K., and Tshwenyane, S. 2003. Atriplex nummularia (Old Man Saltbush): a potential forage crop for arid regions of Botswana. Pakistan Journal of Nutrition, 2(2): 72-75.

Allison, C.D. 1985. Factors affecting forage intake by range ruminants: a review. Rangeland Ecology \&
Management/Journal of Range Management Archives. 38(4): 305-311.

AOAC, 2000. Official Methods of Analysis (17th ed). The Association of Official Analytical Chemists, Gaithersburg, MD, USA.

Bamikole, M.A., Akinsoyinu, A.O., Ezenwa, I., Babayemi, O.J., Akinlade, J., and Adewumi, M.K. 2004.Effect of six- weekly harvests on the yield, chemical composition and dry matter degradability of Panicum maximum and Stylosanthes hamata in Nigeria. Grass and Forage Science. 59(4): 357-363.

Barry, T.N., McNeill, D.A., and McNabb, W.C., 2001, January. Plant secondary compounds; their impact on forage nutritive value and upon animal production. In Proceedings of the XIX international grassland congress (pp. 445452). Fundacao Estudos Agrarios Luiz Queiroz (FEALQ).

Berthelot, M. 1959. Estimation of serum urea. Report Chem. Applique. 1: 248.

Brown, D., Ngambi, J.W., and Norris, D. 2018. Effect of tanniniferous Acacia karroo leaf meal inclusion level on feed intake, digestibility and live weight gain of goats fed a Setaria verticillata grass hay-based diet. Journal of Applied Animal Research. 46(1): 248-253.

Chriyaa, A., and Boulanouar, B. 2000. Browse foliage as a supplement to wheat straw for sheep. In Fodder shrub development in arid and semi-arid zones. Volume 2. Proceedings of the Workshop on Native and Exotic Fodder Shrubs in Arid and Semi-arid Zones, 27 October-2 November 1996, Hammam et tunisia (pp. 476-484). International Center for Agricultural Research in the Dry Areas (ICARDA).

Coles, E.H. 1986. Veterinary Clinical Pathology. 4th Edn. Sunders W. B. Co., Philadelphia, London.

Duncan, D.B. 1955.Multiple ranges and multiple F. Test. Biometrics.11: 1.

Eissa, M.M., EL-Wakeel, E.L.A., Saber, A.M., Khattab, A.R., and Sadek, W.M.A. 2015. Response of Barki lambs to diets 
containing Cassava and Treated wheat straw with Prosopis or Acacia saligne (leaves \& twigs) under semi-arid area in Egypt. Egyptian Journal of Animal Production. 52(4): 79-87.

El-Shaer, H.M., Ali, F.T., Morcos, N.Y.S., Emam, S.S., and Essawy, A.M. 2005. Seasonal changes of some anti-nutritional factors contents of some halophytic shrubs and the effect of processing treatments on their utilization by sheep under desert conditions of Egypt. Egyptian J. Nutr. Feeds, 8(1): 417-431.

FAO, 2008. The state of food and agriculture in Asia and the Pacific region, Food and Agriculture Organization, Rome, Italy, Available at: http://www.fao.org/docrep/010/ai411e/ai4 $11 \mathrm{e} 00 . \mathrm{htm}$

Fayed, A.M., El-Essawy, A.M., Eid, E.Y., Helal, H.G., Abdou, A.R., and El Shaer, H. M., 2010. Utilization of alfalfa and Atriplex for feeding sheep under saline conditions of south Sinai, Egypt. Journal of American Science. 6(1): 1447-1460.

Gemeda, B.S., and Hassen, A., 2015. Effect of tannin and species variation on in vitro digestibility, gas, and methane production of tropical browse plants. AsianAustralasian Journal of Animal Sciences. 28(2): 188.

Getachew, G., Blümmel, M., Makkar, H.P.S., and Becker, K. (1998). In vitro gas measuring techniques for assessment of nutritional quality of feeds: a review. Animal Feed Science and Technology. 72(3-4): 261-281.

Getachew, G., Makkar, H.P.S., and Becker, K. 2002. Tropical browses: contents of phenolic compounds, in vitro gas production and stoichiometric relationship between short chain fatty acid and in vitro gas production. J. Agric. Sci. Camb., 139: 341-352.

Helal, H.G., Nassar, M.S., Badawy, H.S., Eid, E.Y., and El-Shaer, H.M. 2018. Comparative nutritional studies of sheep and goats fed cultivated tree legumes mixture under desert condition.
American-Eurasian Journal of Sustainable Agriculture. 12(1): 10-21.

Hintsa, K., Berhe, A., Balehegn, M., and Berhe, K. 2018. Effect of replacing concentrate feed with leaves of Oldman saltbush (Atriplex nummularia) on feed intake, weight gain, and carcass parameters of highland sheep fed on wheat straw in northern Ethiopia. Tropical Animal Health and Production, 50(7): 1435-1440.

Hussain, F., and Durrani. M. J. 2008. Mineral composition of some range grasses and shrubs from Harboi rangeland Kalat, Pakistan. Pakistan Journal of Botany 40: 2513-2523

Isah, O.A., Fayemi, P.O., Gazaly, M.B., and Aderinboye, R.Y. 2012. Nutritional characteristics of four browse plants consumed by free-ranging ruminants in Western part of Nigeria. African Journal of Agricultural Research. 7(12): 19441949.

Khazaal, K., Dentinho, M.T., Ribeiro, J.M., and Ørskov, E.R. 1995. Prediction of apparent digestibility and voluntary intake of hays fed to sheep: comparison between using fibre components, in vitro digestibility or characteristics of gas production or nylon bag degradation. Animal Science. 61(3): 527-538.

Khazaal, K.A., Parissi, Z., Tsiouvaras, C., Nastis, A., and Orskov, E.R. 1996. Assessment of phenolics-related antinutritive levels using the in vitro gas production technique: A comparison between different types of polyvinylpolypyrrolidone or polyethylene glycol. Journal of the Science of Food and Agriculture. 71(4): 405-414.

Le Houerou, N.H. 1991. Feeding shrubs to sheep in the Mediterranean arid zone: intake, performance and feed value. In the IVth International Rangeland Congress, pp. 623-628. Montpellier, France.

Mahmoud, H.A. 2001. Physiological and nutritional studies on sheep feeding certain halophytic plants in Sinai (Doctoral dissertation, M. Sc. Thesis, Fac. of Sci., Cairo University, Giza, Egypt). 
McDowell, L.R. 1992. Minerals in Animal and Human Nutrition. Academic Press, San Diego, CA. pp. 49

Menke, K.H. 1988. Estimation of the energetic feed value obtained from chemical analysis and in vitro gas production using rumen fluid. Animal Research and Development. 28: 7-55.

Mueller- Harvey, I. 2006. Unravelling the conundrum of tannins in animal nutrition and health. Journal of the Science of Food and Agriculture. 86(13): 2010-2037.

Norman, H., Masters, D., Wilmot, M., Rintoul, A. 2008.Effect of supplementation with grain, hay or straw on the performance of weaner Merino sheep grazing old man (Atriplex nummularia) or river (Atriplex amnicola) saltbush. Grass and forage science. 63: 179-192.

NRC (National Research Council), 1985.Nutrient requirements of domestic animals, Nutrient Requirements of Sheep National Academy Press, Washington D.C., USA.

NRC (National Research Council), 2001.Nutrient Requirement of Dairy Cattle.7th Revised Edition. National Academy Press, Washington, D.C.

Obeidat, B.S., Mahmoud, K.Z., Maswadeh, J.A., and Bsoul, E.Y. 2016.Effects of feeding Atriplex halimus L. on growth performance and carcass characteristics of fattening Awassi lambs. Small ruminant research. 137: 65-70.

Okunade, S.A., Isah, O.A., Aderinboye, R.Y. and Olafadehan, O.A. 2014. Assessment of chemical composition and in vitro degradation profile of some guinea savannah browse plants of Nigeria. Tropical and Subtropical Agroecosystems. 17(3): 529-538.

Oshodi, A.A. 1992. Proximate composition, nutritionally valuable minerals and functional properties of Adenopus breviflorus benth seed flour and protein concentrate. Food Chemistry. 45: 79-83.

Porter, L. J., Hrstich, L. N., and Chan, B. G. (1985).The conversion of procyanidins and prodelphinidins to cyanidin and delphinidin. Phytochemistry. 25(1): 223230.

Reed, J.D., 1995. Nutritional toxicology of tannins and related polyphenols in forage legumes. Journal of Animal Science. 73(5): 1516-1528.

Rehman, A., Mackintosh, J. B., Fortune, J. A., and Warren, B. E. 1994. Can the voluntary feed intake of wheat straw in sheep be improved by mixing with saltbush (Atriplex amnicola). In Can the voluntary feed intake of wheat straw in sheep be improved by mixing with saltbush (Atriplex amnicola)? Australian Society of Animal Production.175-177.

RodKey, F.L. 1965. Separation and determination of the total globulins of human serum. Clinical Chemistry. 11(4): 488-494.

Rohweder, D., Barnes, R.F., and Jorgensen, N. 1978. Proposed hay grading standards based on laboratory analyses for evaluating quality. Journal of Animal Science. 47(3): 747-759.

Roundy, B. A., Ruyle, G. B., and Ard. J. 1989. Estimating production and utilization of Jojoba. J. Range Mange. 42: 7578.

Rubanza, K.D.C., Shem, M.N., Otsyina, R., Ichinole, T., and Fujihara, T. 2003. Nutritive evaluation of some browse tree legume foliages native to semi-arid areas in western Tanzania. Asia-Aust. J. Anim. Sci. 16: 1429-1437.

Sadek W.M.A., Elwakeel, E.A., Saber, A.M., Abdel-Mawla, L.F., Anwar, M.M., Ghobashy, H., and Eiss, M.M. 2020. Comparative study of tanniniferous shrubs as an alternative source of feed on performance of sheep vs. goats under semi-desert conditions of the north western-coast of Egypt. International Journal of Current Research in Biosciences and Plant Biology. 7 (3): 2349.

Salem, H.B., and Smith, T. 2008. Feeding strategies to increase small ruminant production in dry environments. Small ruminant research. 77(2-3): 174-194.

Salem, H.B., Makkar, H.P.S., Nefzaoui, A., 
Hassayoun, L., and Abidi, S. 2005. Benefit from the association of small amounts of tannin-rich shrub foliage (Acacia cyanophylla Lindl.) with soya bean meal given as supplements to Barbarine sheep fed on oaten hay. Animal Feed Science and Technology. 122(1-2): 173-186.

SAS, 2003.Statisticalanalysis systems user's guide.SAS Institute Inc., Raleigh, North Carolina, USA.

Seelig, H.P., and Wust, H. 1969. Determination of serum creatinine. Arztl Labor, 15, 34.

Shaker, Y.M., Ibrahim, N.H., Younis, F.E., and El-Shaer, H.M. 2014.Effect of feeding some salt tolerant fodder Shrubs mixture on physiological performance of Shami goats in Southern Sinai, Egypt. Journal of American Science. 10(2s): 66-77.

Silanikove, N., Gilboa, N., Perevolotsky, A., and Nitsan, Z., 1996. Goats fed tannincontaining leaves do not exhibit toxic syndromes. Small Ruminant Research. 21(3): 195-201.

Theodorou, M.K., Williams, B.A., Dhanoa, M.S., McAllan, A.B., and France, J. 1994. A simple gas production method using a pressure transducer to determine the fermentation kinetics of ruminant feeds. Animal Feed Science and Technology. 48(3-4): 185-197.

Van Soest, P.J. 1994. Nutritional Ecology of Ruminants, 2nd edn. Cornell University Press, $476 \mathrm{pp}$.

Waghorn, G.C., and Shelton, I.D. 1997. Effect of condensed tannins in Lotus corniculatus on the nutritive value of pasture for sheep. Journal of Agriculture Science, Cambridge. 128: 365-372.

Wilkinson, J.H., Baron, D.N., Moss, D.W., and Walker, P.G. 1972. Standardization of clinical enzyme assays: a reference method for aspartate and alanine transaminases. Journal of Clinical Pathology. 25(11): 940.

Wilson, A.D. 1977. The digestibility and voluntary intake of the leaves of trees and shrubs by sheep and goats. Aust. J. Agric. Res. 28: 501-508.

Zhou, H., Li, M., Zi, X., Xu, T., and Hou, G. 2011.Nutritive value of several tropical legume shrubs in Hainan province of China. Journal of Animal and Veterinary Advances. 10(13): 1640-1648.

\section{How to cite this article:}

Mahmoud Yassin Mohamed, Adel M. Saber, El- Saeed A. El-Wakeel, Mohamed M. Anwar, HeshamGhobashy, Lamiaa F. Abdel-Mawla and Mohamed M. Eissa. 2020. Partial Replacement of Berseem Hay by Atriplex halimus and Atriplex nummularia Nutrients Utilization in Barki Sheep. Int.J.Curr.Microbiol.App.Sci. 9(07): 3169-3186. doi: https://doi.org/10.20546/ijcmas.2020.907.371 